\title{
OCCURRENCE OF Spaethiella coccinea BOHEMAN (COLEOPTERA: CHRYSOMELIDAE, HISPINAE) ON Theobroma grandiflorum [WILLDENOW EX SPRENGEL] SCHUMMAN, (STERCULIACEAE), IN MANAUS, AMAZONAS, BRAZIL ${ }^{1}$
}

\author{
Maria das Graças Vale BARBOSA ${ }^{2}$, Claudio Ruy Vasconcelos FONSECA ${ }^{3}$, \\ Jorge Augusto de Oliveira GUERRA ${ }^{4}$
}

\begin{abstract}
A preliminary study on the ocurrence of Spathiella coccinea Boh. (Coleoptera) on Theobroma grandiflorum (cupuassu), native Amazonian fruit plant, are reported. S. coccinea is known to feed on leaves of many species of palm, and has been found in Elaeis guineensis (Palmaceae) leaves. From September 1994 to February 1996 observations were made on the behavior and seasonal aspects of $S$. coccinea and larvae, pupae and adults found on the leaves of cupuassu were hand collected. The highest number of insects was found in the rainy season February 1995.
\end{abstract}

Key Words: Coleoptera, Chrysomelidae, Spathiella coccinea, Cupuassu, Theobroma grandiflorum Ocorrência de Spaethiella coccinea Boheman (Coleoptera: Chrysomelidae, Hispinae) em Plantas de Theobroma grandiflorum [Willdenow ex Sprengel] Schumman, (Sterculiaceae), em Manaus, Amazonas, Brasil

RESUMO - A ocorrência de Spathiella coccinea Boh. em plantas de Theobroma grandiflorum Schum. (cupuaçuzeiro), fruteira nativa da região Amazônica é aqui registrada. S. coccinea é conhecida como um Coleoptera que se alimenta de folhas de palmeiras de diversas espécies tendo sido encontrado na região de Tefé, alimentando-se de folhas de dendezeiros Elaeis guineensis. Durante dezoito meses foram feitas observações sobre o comportamento sazonal desses besouros, coletandose manualmente larvas, pupas e adultos sobre e sob as folhas de cupuaçuzeiros. Encontrou-se o maior número desses indivíduos nos meses correspondentes ao periodo mais chuvoso.

Palavras Chave: Coleoptera, Chrysomelidae, Spathiella coccinea, Cupuaçu, Theobroma grandiflorum.

The cupuassu (Theobroma grandiflorum) is a native Amazonian fruit tree that is one of the species with the highest economic potential as its fruits are considered to be the biggest and best of their kind in the regional flora. The cupuassu has been planted with increasing frequency, mainly for industrial purposes, due to the yield of their perennial Fruits (Agenda do CNPq, 1985; Calzavara, 1987; Calzavara et al,
1988). Despite the economic value that it has aquired, little is known about the entomology of this plant (Silva, 1976; Falcão \& Lleras, 1983; Barbosa, 1994; Venturieri, 1994).

Among all the beetles that visited this plant in our survey, Spaethiella coccinea Boheman (Chrysomelidae, Hispinae, former Cassidinae Lawrence \& Newton, 1995) was observed feeding on the leaves of cupuassu trees

1 This study was funded by Programa de Capacitação de Recursos Humanos para o Desenvolvimento - RHAE processo 360290/94-9

2 Graduate student, at Instituto Nacional de Pesquisas da Amazônia - INPA, C. P. 478, CEP 69011-970 Manaus, Amazonas, Brazil. E-mail : graca@inpa.gov.br

3 Instituto Nacional de Pesquisas da Amazônia - INPA Researcher, C. P, 478, CEP 69011-970 Manaus, Amazonas, Brazil

4 Instituto de Medicina Tropical do Amazonas - IMT-AM, Av. Pedro Teixeira, 25, Manaus, Amazonas, Brazil. 
(Barbosa, 1994). This species is known to attack leaves of many species of palm trees, and has been found in the Tefé region eating Elaeis guineensis leaves (Garcia, 1996).

Some species of Spaethiella feed on leaves of many different plants, such as palms and cacao (Bruch, 1939; Bondar, 1939; 1940; Genty et al., 1978). Bondar (1939), observed that these insects do not cause serious damage in cultivated plants, since they do not consume a large amount of plant leaves, they have low rates of reproduction and the individuals in the population are widely dispersed. However, studies about the relation between insetcs that attack Elaeis guineensis leaves, like, the Hemiptera, Lepidoptera and Coleoptera, and the fungi of the genus Pestalotiopsis through the damage caused by the insects, can infect the leaves (Genty, 1978; Genty et al., 1975; 1981; 1983; Vessey, 1981). Many espicies of this fungi was found associated with leaf spot on the coconut palms (Tuner, 1981) and indirectly, jeopardize the plant's economic value (Garcia et al., 1996).

Given the economic value of this fruit tree and the likelihood that $S$. coccinea can affect its production, we decided to make observations on the behavior and to record the seasonality of this beetle on cupuassu trees.

To observe the beetles on cupuassu leaves we visited the site once or twice every 15 days from September 1994 to February 1996. The study was done in a private property located in the suburbs of Manaus, Amazonas, where there were nearly 1,000 cupuassu trees. Observations were made in 50 trees located on the the front, 50 trees on the lateral, 50 on the middle and 50 on the bordering of the forest.

The immature (larvae and pupae) and adults observed on the plants, were hand-collected and the leaves on which they were feeding were cut, put in plastic bags and taken to the laboratory where the separation and counting of the material was done. The larvae and pupae were always found on the inderside of the leaves in a cocoonlike protective cover (Figs. 1-5). This cocoon is a thread like structure built by the female over the eggs after oviposition. The female builds the cocoon with her own excrement, apparently. protecting the egg, the larva and the pupa (Bondar, 1939).

During the course of this study we collected 96 larvae, 75 pupae and 27 adults of $S$. coccinea on cupuassu leaves (Tab. 1). The highest number of individual insects $(85 \%)$ wascollected on plants in areas bordering the forest, while we found only $5 \%$ on trees located in the middle, $10 \%$ on trees at the sides and $0.5 \%$ on trees at the front of plantations. The month with the highest peak in the number of insects was during the rainy season in February 1995 (Fig. 6).

We noticed that the larvae, pupae and adults, of these beetles were always found on the upper surface and occasionally on the underside the leaves of cupuassu trees. The larvae of Spaethiella tristes have the opposite behaviors they were found feeding mainly on the epidermis and parenquima underneath the native palm leaflets leaving only the epider- 

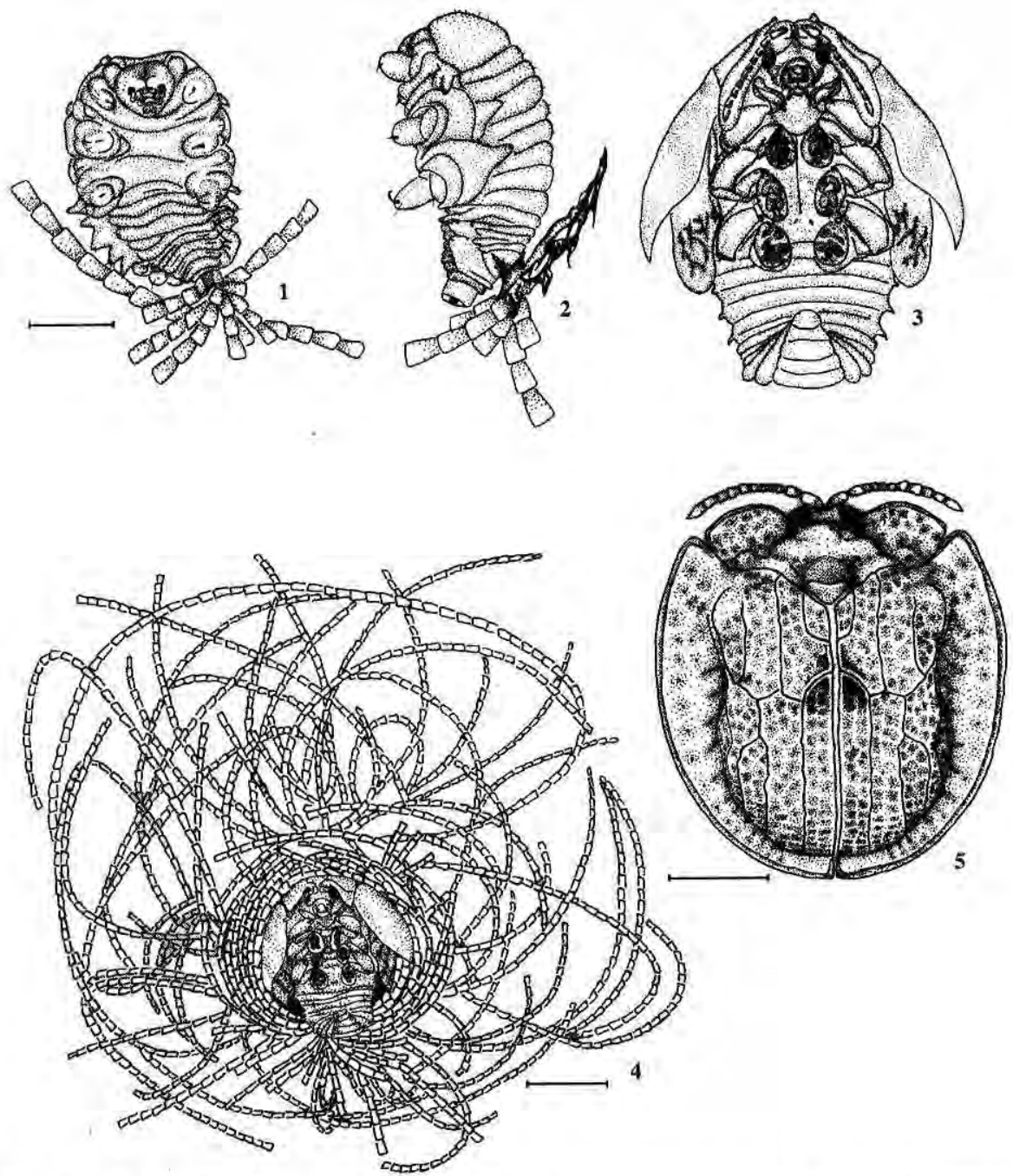

Figure 1-5. Spaethiella coccinea Boh. Figure 1 e $2(1.0 \mathrm{~mm})$ larvae Figure $3(1.0 \mathrm{~mm})$ pupae Figure $4(2.0 \mathrm{~mm})$ pupae underneath a cocoon-like protective cover and Figure $5(1.0 \mathrm{~mm})$ adult dorsal view. 
Table 1. The numbers of larvae, pupae and adults of Spaethiella coccinea collected on the cupuassu trees from September/1994 to February/1996

\begin{tabular}{|c|c|c|c|c|c|c|c|c|c|c|c|c|c|c|c|c|c|c|c|}
\hline \multirow[t]{2}{*}{ Stages } & \multicolumn{15}{|c|}{ MONTHS } & \multicolumn{4}{|r|}{ Total } \\
\hline & $S$ & 0 & $N$ & $D$ & $J$ & $\mathrm{~F}$ & $M$ & A & M & $J$ & $\mathrm{~J}$ & A & $S$ & 0 & $\mathrm{~N}$ & D & $\mathrm{J}$ & $\mathrm{F}$ & \\
\hline Larvae & 2 & 3 & 2 & 4 & 2 & 54 & 6 & 4 & 8 & 1 & 10 & 0 & 0 & 0 & 0 & 0 & 0 & 1 & 96 \\
\hline Pupae & 0 & 0 & 0 & 0 & 0 & 20 & 6 & 5 & 4 & 15 & 14 & 9 & 0 & 0 & 0 & 0 & 0 & 2 & 75 \\
\hline Adults & 1 & 1 & 1 & 2 & 0 & 12 & 2 & 0 & 4 & 1 & 1 & 2 & 0 & 0 & 0 & 0 & 0 & 0 & 27 \\
\hline
\end{tabular}

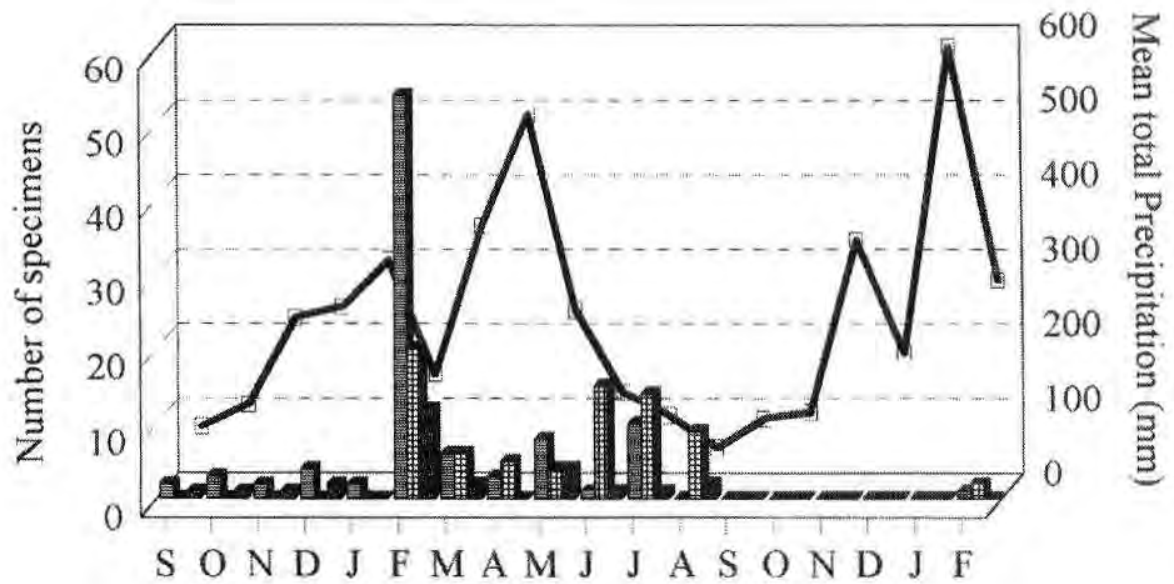

Months

Larvae Pupae Adults - Precipitation

Figure 6. Monthly average of temperature, relative humidity, rainfall and population fluctuation of larvae, pupae and adults of Spathiella coccinea Boh. during 18 consecutive months of collections on the cupuassu trees, from September/1994 to February/1996.

mis of the upper surface untouched. leaves the "cocoon" after feeding on The larvae of this species feed on some parts of the leaf. The damage about $4 \mathrm{~cm}^{2}$ of the leaf and their excre- caused by these beetles on the ment was fixed on their last abdomi- cupuassu trees is not considered very nal segment in a long filamented serious. However, the presence of form, like a "cocoon" to protect the these insects on the plants could belarvae (Bondar, 1940; Lima 1955). Af- come the cause of many problems, ter emergence the adult remain under since the damage can provide open the cocoon until the body hardens and door to entry of microorganism, that darken to adult coloration that may take many hours (Garcia, 1996).

We observed that once the adult exoskeleton hardens, S. coccinea can jeopardize the plants production and its high economic value.

In this study we provide information for the farmers, who must be 
alert to the presence of these insects (larvae and adults) on their crops and take care that the populations of these insects not increase out of control.

\section{ACKNOWLEDGMENTS}

We are grateful to Marcos Vinicius Bastos Garcia of the Empresa Brasileira de Pesquisa Agropecuaria EMBRAPA/AM helped to improve the manuscript, Dr Philip Fearnside helped with rewriting and Nara Vieira da Silva made the drawings. We also thank the field assistants Luiz Aquino and Francisco Felipe Xavier..

\section{Literature cited}

Agenda Cnpq 1985. Estrangeiros querem o cupuaçu. 7(11): 8

Barbosa, M. G. V. 1994. Contribuição ao conhecimento da coleopterofauna visitante de cupuaçu (Theobroma grandiflorum [Willdenow ex Sprengel ]) Schumman em um bairro de Manaus Amazonas. Dissertação de Mestrado, Instituto Nacional de Pesquisas da Amazonia / Universidade do Amazonas. 143p.

Bruch, C. 1939. El cásido de las palmeras Hemisphaerota crassicornis Spaeth (Col.: Cassid.) Rev. Fac. Agr: La Plata, 3:19-25.

Bondar, G. 1939. Insetos nocivos ao cacaueiro. Inst. de cacau da Bahia. Boletim Técnico, no. $5,112 \mathrm{p}$.

Bondar, G. 1940. Insetos nocivos e molestias do coqueiro (Cocos nucifera) no Brasil. Salvador, Tipografia Naval, 160p.

Calzavara, B. B. G. 1987. Cupuacuzeiro. Theobroma grandiflorum Schum. Serie Cultivos Pioneiros Boletim do IPEAN Belem, 11p.
Calzavara, B. B. G., Muller, C. H.; Kahwage, O. N. C. 1988. Importância do cultivo do cupuaçu. Toda Fruta, 15p.

Falcao, M. A.; Lleras, E. 1983. Aspectos fenologicos, ecologicos e de produtividade do cupuacu (Theobroma grandiflorum Willdenow ex Spreng. Schum.) Acta Amazonica, 13(5-6):725-735.

Garcia, M. V. B., Pamplona, A. M. S. R., Moraes, L. A. C.; Araujo, J. C. A. 1996. Observações sobre a biologia de Spaethiella tristis (Boh.) (Coleoptera: Chrysomelidae) e danos causados ao dendezeiro. An. Soc, Entomol. Brasil, 25(2):339-342.

Genty, Ph. 1978. Morphologie et biologie d'un lépidoptère défoliateur du palmier à huile en Amérique latine, Stenoma cecropia Meyrick. Oleagineux, 30(8-9):421-427.

Genty, Ph., Desmier de Chenon, R.; Morin, J. P. 1978. Les ravageurs du palmier a huile en Amérique Latine. Oleagineux, 33 (7):325-420.

Genty, Ph., Gildardo Lopez, J.; Mariau, D. 1975. Dégâts de Pestalotiopsis induits par des attaques de Gargaphia en Colombie. Oleagineux, 30(5):199-204.

Lawrence, J. F.; Newton Jr. A. F. 1995. Families and subfamilies of Coleoptera (with selected genera, note, references and data on family-group names). Eds. J. Pakaluk and S. A. Slipinski, p907.

Silva, M. F. 1976. Insetos que visitam o cupuaçu Theobroma grandiflorum (Willd ex Spreng) Schum. (Sterculiaceae) e indice de ataque nas folhas. Acta Amazonica, 6(1):9-54.

Venturieri, G. A. 1994. Floral Biology of cupuassu Theobroma grandiflorum (Willdenow ex Sprengel) Schumam. Ph.D. Thesis University of Reading. 211p.

Vessey, J. C. 1981. Control of a leaf spot on oil palm in Honduras with insecticides. Oleagineux, 36(5):229-231. 